\title{
FISCAL DECENTRALIZATION, INTERNAL CONTROL SYSTEM, ACCOUNTABILITY OF LOCAL GOVERNMENT AND AUDIT OPINION
}

\author{
Ni Ketut Rasmini ${ }^{1}$ \\ Putu Riesty Masdiantini \\ ${ }^{1,2}$ Udayana University, Bali, Indonesia \\ email: tut_ras@yahoo.com
}

\begin{abstract}
The objective of this research is to examine the influence of fiscal decentralization and internal control system on the accountability of local government financial reporting with audit opinion in the previous year as the moderator variable. The result shows that fiscal decentralization, which utilize the regional independency level and level of dependency towards the central government as proxy, does not influence the accountability of local government's financial reporting. M eanwhile, internal control system, which utilizes the weakness of internal control system as proxy, has a negative effect on the accountability of local government's financial reporting. The interaction test shows that audit opinion in the previous year is not able to strengthen the influence of the region's level of independence, is unable to weaken the influence of the region's level of dependence andis able to weaken the influence of internal control system on the accountability of local government financial reporting.
\end{abstract}

Keywords: Fiscal decentralization; internal control system; previous year audit opinion; and accountability of financial reporting

\section{DESENTRALISASI FISKAL, SISTEM PENGENDALIAN INTERNAL, AKUNTABILITAS PELAPORAN KEUANGAN DAERAH, DAN OPINI AUDIT SEBELUMNYA}

\begin{abstract}
ABSTRAK
Penelitian bertujuan menguji pengaruh desentralisasi fiskal dan sistem pengendalian internal terhadap akuntabilitas pelaporan keuangan pemerintah daerah dengan opini audit pada tahun sebelumnya sebagai pemoderasi. Hasil penelitian menunjukkan bahwa desentralisasi fiskal, yang memanfaatkan tingkat independensi daerah dan tingkat ketergantungan terhadappemerintah pusat sebagai proksi, tidak mempengaruhi akuntabilitas pelaporan keuangan pemerintah daerah. Sementara itu, system pengendalian internal, yang memanfaatkan kelemahan sistem pengendalian internal sebagai proksi, memiliki efek negatif pada akuntabilitas pelaporan keuangan pemerintah daerah.Uji interaksi menunjukkan bahwa opini audit pada tahun sebelumnya tidak mampu memperkuat pengaruh tingkat kemandirian daerah, tidak mampu melemahkan pengaruh tingkat ketergantungan daerah dan mampu melemahkan pengaruh sistem pengendalian internal terhadap akuntabilitas pelaporan keuangan pemerintah daerah.
\end{abstract}

Kata Kunci: Desentralisasi fiskal, sistem pengendalian internal, opini audit sebelumnya, akuntabilitas pelaporan keuangan

DOI: https://doi.org/10.24843/J IAB.2018.v13.i02.p06

\section{INTRODUCTION}

In 1998, Indonesia entered a new phase in their governance. The transformation of the governance system from centralistic to a decentralist changed the relationship between the people and the country (Bennet, 2010). Decentralization is defined as the process of political devolution, fiscal and decisionmaking from centralgovernment to local government. The decentralization process includesthree dimensions ofpolitical decentralization, fiscal decentralization and administrative decentralization (Moisiu, 2013). Fiscal decentralization is the core component of decentralization because to exercise the authority given to them, decent sources of funding are needed 
(Wasistiono, 2002). Fiscal decentralization resulted in the financial relationship between central and regional, and the financial relationship between central and regional has then brought forth the region's aurthority to search for income sources (Yuswanto, 2007).

In the process of delegating this authority, there is a relationship between the people/principal and the government/agent, legislative/principal and the local government/agent, and also between the people/ principal and the legislative/agent (Arifianti et al., 2013). The agency theory by Jensen and Meckling (1976) explained that the agency relationship may lead to the condition of asymmetrical information because agents are in a position that has more information compared to the principals. The existence of this information asymmetry may also lead to conflict between the principals and agents (Irmawati and Pratolo, 2016).

Accountability is believed to be able to change the governance condition, from unable to provide good public services and corrupted to a more democratic structure (Erryana and Setyawan, 2016). Financial accountability is one of the public accountability which is the responsibility to provide financial integrity, disclosure, and conformity to the law and regulations. The target of financial accountability is the Local Government Financial Reporting (LGFR) (Yuliati et al., 2017). The local government currently submits the accountability report to three parties, namely the central government, the Regional Representative Council (DPRD) and the people (Hudaya et al., 2015). The LGFR will be examined by external auditors, namely the Audit Board of the Republic of Indonesia (BPK RI). The preparation and examination of the local government financial report is the step to achieve accountability in the government's financial reporting. The Audit Board of the Republic of Indonesia provides five types of audit opinion, namely Unqualified opinion (UO), Modified Qualified opinion (MQO), Qualified opinion (QO), Adverse opinion (AO), and Disclaimer Opinion (DO)(Fontanella and Rossieta, 2014). Providing an audit opinion regarding the LGFR by the Audit Board of Indonesia is a form of accountability, because it is a form of the local government's accountability towards the people that the financial report has been presented fairly, consistent with the Public Accounting Standards (SAP) and is free from material misrepresentation (Nurhidayati, 2017). In the budget year 2016, the Audit Board of Indonesiagave an unqualified opinion on the local revenue financial report of the nine regency/city government in Bali Province. This shows that in the budget year of 2016, the local government in Bali Province, starting from the provincial level, until the regency/city level, attained an unqualified opinion (BPK Perwakilan Provinsi Bali, 2017).
The main characteristic of a region capable of conducting autonomy is the regional financial ability, which means that the region must have the authority to search for the source of funds available in the region, manage and use their own funds to finance government activities, and the dependency towards the central government must be as minimum as possible so that the Locally Generated Revenue (LGR) becomes the region's source of funds (Halim, 2011).Bali Province is among the provinces in Indonesia that have less natural resources than other regions in Indonesia. This limitation compels the regencies/cities in Bali Province to search for sources of LGR that can be used to fund their regional expenditure in order to maintain an optimal level of public service (Yudani, 2008).

Based on the data attained from the Regional Asset and Finance Management Board (BPKAD) of Bali Province and the Audit Board of the Republic of Indonesia in Bali Province, over the last six years, from 2011-2016, the LGR level in regencies/cities in Bali Province has consistently experienced improvements. However, the composition of the local revenue in regencies/cities in Bali Province is still dominated by transfer revenue. Fontanella and Rossieta (2014) argued that the implementation of fiscal decentralization complemented with a set of management regulations and decent local fiscal decentralization, would result in the increase in quality of the local government management and financial reporting, with audit opinion from the Audit Board of the Republic of Indonesia as the proxies. This is in contrary with the phenomena that occurred in the nine regencies/cities in Bali Province. Even though the composition of the local revenue in the regencies/ cities in Bali Province is still dominated by transfer revenue, all the regencies/cities in Bali Province attained an unqualified opinion on their LGFR in the year of 2016.

One of previous studies examining the factors that can influence local government financial reporting accountability is the research by Fontanella and Rossieta (2014) which revealed that fiscal decentralization with the regional independency level as the proxy has a positive influence on the accountability of local government financial reporting, while the dependency level of the region towards central government does not influence the accountability of the local government financial reporting. Meanwhile, the research by Irmawati and Pratolo (2016) found that regional independency level does not have significant influence on the accountability of the local government financial reporting. On the other hand, the research by Rinaldi et al., (2007) andSaputra (2012) stated that fiscal decentralization could trigger the occurrence of corruption. 
Financial reports must be formed based on good internal control system to produce a reliable financial report. The role of the internal control system is to increase performance, transparency, and the accountability of the Country's financial management (Kawedar, 2010). The implementation of good internal control mechanism will assure the quality and performance of the government as a whole, because internal control results in the reliability of the financial report, protects the country's assets and assures compliance towards the prevailing law (Darmawati, 2017). The government is the body that has been given the trust of the people to manage the people's wealth. The government is also responsible in providing information or show signals to provide assurance for the people. (Nainggolan and Purwanti, 2016). The effort to achieve transparent and accountable governance does not mean that there are no difficulties. The possible difficulty that may occur is frauds in the governance process. Frauds may occur due to weak internal control in an organization (Agustina and Riharjo, 2016).

Nalurita (2015), Munawar, et al., (2016), Darmawati (2017) and Rosadi et al., (2017) found that weak internal control system has a significant and negative influence on the opinion of the Audit Board of the Republic of Indonesia. Different results were seen in the research by Agusti, et al (2014)in which weak internal control system does not influence the level of accountability and transparency of the Ministry/Institution. Nurdiono, et al., (2015) found that internal control effectivity does not have a significant influence on the LGFR's audit result. This is consistent with the research by Safitri and Darsono (2015) which stated that weak internal control system does not have a significant influence on the opinion given by the Audit Board of the Republic of Indonesia.

In previous studies, there are inconsistencies in the research results. This could be due to other variables that can influence the accountability of the local government financial reporting with audit opinion as the proxy. Local government financial reporting accountability can be influenced by many factors, among others by the audit opinion in the previous year (Fatimah, etal., 2014; Nalurita, 2015; Nurdiono et al., 2015). The research by Simon (1957), March and Simon (1958) in Bazerman (1994) revealed that individual decision is limited by their rationality and that we can comprehend decision making better through actual explanations, instead of normative. Based on the bounded rationality theory, auditor can expand the control system audit if the opinion in the previous year is an adverse opinion. Conversely, if the opinion in the previous year is unqualified, auditors will not expand the control system audit scope because they are influenced by the opinion in the previous year (Nurdiono etal., 2015).

According to the International Standard on Auditing (ISA) 710, audit opinion in the previous year has a relation with the opinion in the subsequent year, while the problem which causes the modification is not solved and the suitable number is yet to be republished or has not been disclosed correctly. This is proven in the research by Malek and Ahmad (2011) and Banimahd, etal., (2013) which show that among the determining factors in the process of preparing the audit opinion report is the audit opinion from the previous year. This result concludes that the auditopinion in the previous year has a direct and positive relationship with the publication of an unqualified opinion audit report in the current year (Fatimah et al., 2014). The issue of solving the previous years recommendation is that it may cause the local government to have difficulties in attaining an unqualified opinion, thus there is a probability that the local government will receive the same audit opinion as the previous year (Atyanta, 2010).

Fiscal decentralization is the authority and responsibility in the preparation, execution, and monitoring of the local government budget (APBD) (Syahrudin, 2006). The fiscal decentralization policy is implemented with a purpose to have the local government capable of performing their functions well and in the attempt to support and increase the finance of the local government in conducting their autonomy (Saragih, 2003).

Accountability is known as one of the main principles of good governance aside from transparency, predictability and participation, thus makes it important to be conducted by government institutions (Suryanto, 2017). Financial reporting is one of the form of management accountability regarding the management of the firm's resources to the parties of interest over a certain period (Fanani etal., 2008).

The definition of internal control formulated by The Committee of Sponsoring Organization's of the Treadway Commission (COSO), which was adopted by the government of the Republic of Indonesia in the Government Regulation (PP) No. 60 Year 2008 regarding the Government Internal Control System (SPIP), is an integral process of the actions and activities conducted continuously by the leaders and all the employees in order to provide adequate assurance that the organizational goals will be achieved through effective and efficient activities, reliable financial reporting, safeguard the nation's assets, and compliance towards the law. Based on this definition, the purposes of internal control areeffective and efficient activities; trustable financial reports; safety of assets, and compliance to the law (Simon et al., 2016). The weakness in the internal control system will become one of the basic for the 
Audit Board of Indonesia auditors to make an opinion. The total internal control system weakness found is one of the criteria by the Audit Board of Indonesia in providing an opinion. Any findings in the internal control system by the Audit Board of Indonesia will be summarized into three category of internal control system weaknessess, namely weakness in the accounting and reporting control system,weakness in the budget execution control system and the weakness in the internal control structure (Nalurita, 2015).

The audit opinion in the previous year is the auditor's opinion in the previous year or one year before the research year. Auditors prepare the audit report every year while also referring to the audit report in the previous year. This is because in auditing, auditors must have an understanding regarding the entity they examine, considering the previous examination results and the follow-up on the recommendations that are significant and related with the purpose of the ongoing audit (Fatimah etal., 2014).

The research conducted by Fontanella and Rossieta (2014) stated that regional independency has a positive and significant influence on the accountability of local government financial reporting with the opinion on the financial report as the proxy. This is seen from the improvement in the audit opinion on the local government that has good independency from year to year. This research result is also consistent with the research by Erryana and Setyawan (2016) and Mudhofar and Tahar (2016). If the region's level of independency is high, there will be an improvement in the participation of the people in developing the region through paying tax and levies. The local government will be demanded to improve the accountability of their financial reports to be accountable to the people. Based on this explanation, the hypothesis is formulated as follows: $\mathrm{H}_{1 \mathrm{a}}$ : The regional independency level has a positive influence on the accountability of the local government's financial reporting.

In an independent condition and low dependency to the central government, the local government would be more able to conduct their financial activities alone, such as in organizing and searching for finance potentials, budgeting and allocations (Mudhofar and Tahar, 2016). The research conducted by Nalurita (2015) explained that the dependency level of the local government towards the central government has a negative and significant influence on the credibility of the local financial statements which is represented by the Audit Board of Indonesia opinion. If the regional level of dependency towards the central government is high, the probability to obtain a good opinion is lower. This is because the local government is not motivated to improve the disclosure of their financial reports as a result of the low demand from external parties for transparency and accountability of the local government financial reports. Based on the explanations above, the hypothesis is formulated as follows:

$\mathrm{H}_{1 \mathrm{~b}}$ : The regional level of dependency towards the central government has a negative influence on the accountability of the local government financial reporting.

Decent internal control is needed as one of the methods to prevent the occurrence of fraud and inaccurate financial reporting (Elmaleh, 2006). The implementation of good internal control system will result in the improvement in the accountability of the local government's finance (Kewo, 2017). The main cause of a bad audit opinion in most cases is the lack of accuracy in recording. Furthermore, auditor must face the lateness and inability of the government institutions to provide their records, which may result in the disclaimer opinion (Ngoepe and Ngulube, 2013). The error due to incomplete records or inaccurate records means that the government entity does not show the real picture of their financial status and the financial statement may have material misstatements (David, 2017). If the internal control system is improved, the discovery of internal control system weaknesses will be lower and this will result in a better opinion regarding the local government financial reports (Munawar, etal., 2016). Based on this review, the hypothesis is formulated as follows: $\mathrm{H}_{2}$ : The weakness of the internal control system has a negative influence on the accountability of the local government financial reporting.

If the independency level is high, the participation of the people in the development of the region through paying taxes and levies will also increase. The local government will be demanded by the people to increase the accountability of their financial reporting (LGFR) in the form of attaining a good auditor opinion on the LGFR. Referring to the theory of bounded rationality, in examining the financial statement auditors will certainly expand their control test if the previous opinion was adverse. Conversely, if it was an unqualified opinion, the auditors will not expand their control test, because they are influenced by the unqualified opinion in the previous period (Nurdiono et al., 2015). The research conducted by Fontanella and Rossieta (2014), Erryana and Setyawan (2016) andMudhofar and Tahar (2016) stated that regional independence has a positive and significant influence on the accountability of the local government financial reporting with the opinion on the financial report as the proxy. This can be seen from the improvement in audit opinion regarding the local government that is independent from year to year. Based on the review above, the hypothesis is developed as follows: 
$\mathrm{H}_{3 \mathrm{a}}$ : Audit opinion in the previous year strengthens the influence of regional independency on the accountability of the local government financial reporting.

If the local government's level of dependency towards the central government is high, they will be less motivated to strive for good accountability in the form of obtaining good audit opinion. The local government will not be motivated to disclose their financial reports because of the low demand for transparency and accountability regarding their LGFR from external parties, which is consistent with the research by Nalurita (2015) and Irmawati and Pratolo (2016). The current year examination will not be expanded if the investigation results regarding the LGFR in the previous year attained an unqualified opinion. The opinion by the Audit Board of Indonesia involves various elements of consideration, and individual considerations that are limited by their rationality. This is in line with the theory of bounded rationality (Nurdiono et al., 2015). Based on this discussion, the hypothesis is formulated as follows: $\mathrm{H}_{3 b}$ : Audit opinion in the previous year weakens the influence of regional level of dependency towards central government on the accountability of local government financial reporting.

If there are low findings of weaknesses in the internal control system, the possibility of obtaining an unqualified opinion becomes high (Darmawati, 2017). In line with the theory of bounded rationality, auditors will expand their control test if they find that the previous opinion is adverse. Conversely, if the previous year opinion is unqualified, auditors will not expand the control test, because they are influenced by the unqualified opinion in the previous year (Nurdiono etal., 2015). Based on the reviews above, the hypothesis formulated is as follows:

$\mathrm{H}_{4}$ : Audit opinion in the previous year weakens the influence of internal control system on the accountability of local government financial reporting.

\section{RESEARCH METHODS}

The population in this research are the local governments in Bali Province over the years of 20112016. The sample in this research is the whole population, namely the local government of the 8 regencies and 1 city in Bali Province. The sampling technique used in this research is a non-probability sampling technique, namely the total population sampling. This research was conducted at the Regional Asset and Finance Management Board (BPKAD) of Bali Province, the Audit Board of the Republic of Indonesia through the website http:// www.bpk.go.id/ and the Audit Board of the Republic of Indonesia in Bali Province to obtain the data regarding the Budget Actualization Report (LRA), audit opinion and findings on the weaknesses in the internal control system of the regency and city governments in Bali Province over the years of 20112016. This research use secondary data and quantitative data.The independent variable in this research is fiscal decentralization with the region's level of independency and level of dependency towards the central government as the proxies, and internal control system with the weakness of the internal control system as proxy. The moderator variable is audit opinion in the previous year and the dependent variable is the accountability of the local government financial reporting. The data analysis technique used is the ordinal logistic regression. The ordinal logistic regression is used if the dependent variable is categorized as an ordinal (rank) (Ghozali, 2013:333). Regression Equation Model 1:

$Y=\alpha+\beta_{1} X_{1}+\beta_{2} X_{2}+\beta_{3} X_{3}+\varepsilon$

Regression Equation Model 2:

$\begin{aligned} Y= & \alpha+\beta_{1} X_{1}+\beta_{2} X_{2}+\beta_{3} X_{3}+\beta_{4} X_{4}+\beta_{5} X_{1} \cdot X_{4}+ \\ & \beta_{6} X_{2} \cdot X_{4}+\beta X_{3} \cdot X_{4}+\varepsilon \ldots \ldots \ldots \ldots \ldots \ldots \ldots \ldots \ldots \ldots \ldots . .(2)\end{aligned}$

Annotation:

$\mathrm{Y} \quad=$ Local Government Financial Reporting Accountability

$\alpha=$ Constant

$\beta_{1}-\beta_{7}=$ Regression Coefficient

$X_{1}=$ Regional Independency Level

$\mathrm{X}_{2}=$ Regional Level of Dependency towards Central Government

$\mathrm{X}_{3}=$ Weakness of the Internal Control System

$\mathrm{X}_{4}=$ Previous Year Audit Opinion

$\mathrm{X}_{1} \cdot \mathrm{X}_{4}=$ Interaction between Regional Independency Level and Previous Year Audit Opinion

$\mathrm{X}_{2} \cdot \mathrm{X}_{4}=$ Interaction between the Regional Level of Dependency towards the Central Government and Previous Year Audit Opinion

$\mathrm{X}_{3} \cdot \mathrm{X}_{4}=$ Interaction between the Weaknesses of the Internal Control System and Previous Year Audit Opinion

$\varepsilon \quad=$ error

\section{RESULTS AND DISCUSSION}

The data analysis conducted in this research utilizes the ordinal logistic regression analysis. The regression model used has fulfilled the model fitting information test, goodness of fit test and testof parallel lines. 
Table 1.

Regression Test Results

\begin{tabular}{ccccccc}
\hline \multirow{2}{*}{ Variable } & & Estimate & $\begin{array}{c}\text { Std. } \\
\text { Error }\end{array}$ & Wald & df & Sig. \\
\hline \multirow{4}{*}{ Threshold } & {$[\mathrm{Y}=1,00]$} & $-10,840$ & 5,917 & 3,357 & 1 & 0,067 \\
& {$[\mathrm{Y}=2,00]$} & $-10,397$ & 5,899 & 3,106 & 1 & 0,078 \\
& {$[\mathrm{Y}=3,00]$} & $-7,215$ & 5,795 & 1,550 & 1 & 0,213 \\
\multirow{5}{*}{ Location } & {$[\mathrm{Y}=4,00]$} & $-7,038$ & 5,791 & 1,477 & 1 & 0,224 \\
& $\mathrm{X}_{1}$ & $-3,579$ & 6,545 & 0,299 & 1 & 0,584 \\
& $\mathrm{X}_{2}$ & $-8,750$ & 7,891 & 1,230 & 1 & 0,267 \\
& $\mathrm{X}_{3}$ & $-0,248$ & 0,105 & 5,587 & 1 & 0,018 \\
\hline
\end{tabular}

Source: Computed Data, 2018

Hypothesis 1a $\left(\mathrm{H}_{1 \mathrm{a}}\right)$ states that the regional independency level has a positive influence on the accountability of the local government financial reporting. Based on the analysis results, the regional independency variable $\left(X_{1}\right)$ has a coefficient value of $-3,579$ with a sig. value of 0,584 . The sig. value 0,584 is greater than 0,05 , thus it can be concluded that hypothesis $1 \mathrm{a}$ is rejected.The research results show that the regional independency level does not influence the accountability of the local government financial reporting. This research result agrees with the research conducted by Irmawati and Pratolo (2016).

Hypothesis $1 \mathrm{~b}\left(\mathrm{H}_{1 \mathrm{~b}}\right)$ stated that the region's level of dependence on the central government has a negative influence on the accountability of the local government financial reporting. The regional level of dependency towards the central government $\left(\mathrm{X}_{2}\right)$ has a coefficient value of $-8,750$ and the sig. value is 0,267 . The sig value 0,267 is greater than 0,05 , thus hypothesis $1 \mathrm{~b}$ is rejected. The research results show that the region's level of dependence on the central government does not influence the accountability of the local government financial reporting. There are some explanations related to this phenomenon. First, the regional level of dependence on the central government, with the general and special allocation fund as the proxy, has already been regulated by the central government and the expense purpose of the allocations are already clear such that the possibilities of misusage are low (Erryana and Setyawan, 2016). The second reason, this may be due to the Regional Incentive Funds (DID) program. The Regional Incentive Funds program can motivate the region make greater archievements (Direktorat Jenderal Bina Keuangan Daerah Kementerian Dalam Negeri, 2013). Various literatures have stated that agency conflict can be overcame by using incentive policies, because with attractive incentives, managers are motivated to increase the welfare of owners and strengthen the monitoring of the company (Ahmad and Septriani, 2008). Motivation or even individual intentions for certain behaviors can be explained by the perspectives in the Theory of Planned Behavior
(TPB). A person will be motivated to behave by considering the possible consequences or implications of his or her behavior, before deciding to act or not make an action or certain behavior. TPB assumed that human are rational creature. This means that their behavior directly depends on the information received systematically (Winarko and Mahadewi, 2013). This research result agrees with the research conducted by Fontanella and Rossieta (2014), Erryana and Setyawan (2016) andMudhofar and Tahar (2016).

Hypothesis two $\left(\mathrm{H}_{2}\right)$ states that internal control system weaknesses have a negative influence on the accountability ofthe local government financial reporting. The internal control system weakness variable $\left(\mathrm{X}_{3}\right)$ has a coefficient value of $-0,248$ and the sig. value is 0,018 . The sig. value 0,018 is less than 0,05 , thus hypothesis 2 is accepted. The research results show that internal control system weaknesses have a negative influence on the accountability of the local government financial reporting. If the internal control system becomes better, there will be less weaknesses found in the internal control system and the opinion regarding the local government financial reporting will improve (Munawar, et al., 2016). This research result supports the findings in the research conducted by Kawedar (2010), Nalurita (2015), Fatimah, et al., (2014), Munawar, et al., (2016), Darmawati (2017) and Rosadi etal., (2017).

Hypothesis $3 \mathrm{a}\left(\mathrm{H}_{3 \mathrm{a}}\right)$ states that the previous year audit opinion strengthens the influence of regional independency level on the accountability of the local government financial reporting. The interaction between the regional independency level and the previous year audit opinion $\left(\mathrm{X}_{1}^{*} \mathrm{X}_{4}\right)$ has a regression coefficient value of $-10,019$ with a sig. value of 0,268 . The sig. value 0,268 is greater than 0,05 , thus hypothesis $3 \mathrm{a}$ is rejected.The research results show that previous year audit opinion is unable to strengthen the influence of regional independence level on the accountability of local government financial reporting. Even if the local government has an unqualified or adverse opinion in the previous year, as long as the local government has a good independency, they tend 
Table 2

Moderation Test Result

\begin{tabular}{ccccccc}
\hline & Variable & Estimate & Std. Error & Wald & df & Sig. \\
\hline \multirow{3}{*}{ Threshold } & {$[\mathrm{Y}=1,00]$} & 38,091 & 34,035 & 1,253 & 1 & 0,263 \\
& {$[\mathrm{Y}=2,00]$} & 38,572 & 34,036 & 1,284 & 1 & 0,257 \\
& {$[\mathrm{Y}=3,00]$} & 42,933 & 34,136 & 1,582 & 1 & 0,208 \\
& {$[\mathrm{Y}=4,00]$} & 43,234 & 34,142 & 1,603 & 1 & 0,205 \\
& $\mathrm{X}_{1}$ & 28,057 & 30,692 & 0,836 & 1 & 0,361 \\
& $\mathrm{X}_{2}$ & 35,642 & 42,646 & 0,699 & 1 & 0,403 \\
& $\mathrm{X}_{3}$ & 1,550 & 0,798 & 3,774 & 1 & 0,052 \\
& $\mathrm{X}_{4}$ & 15,409 & 10,374 & 2,207 & 1 & 0,137 \\
& $\mathrm{X}_{1} * \mathrm{X}_{4}$ & $-10,019$ & 9,051 & 1,225 & 1 & 0,268 \\
& $\mathrm{X}_{2} * \mathrm{X}_{4}$ & $-14,264$ & 12,962 & 1,211 & 1 & 0,271 \\
& $\mathrm{X}_{3} * \mathrm{X}_{4}$ & $-0,496$ & 0,246 & 4,057 & 1 & 0,044 \\
\hline
\end{tabular}

Source: Computed Data, 2018

to have good financial reporting accountability. Deegan (2000)explained that the legitimation theory has a view that there is a "social contract" between the organization and the environment in which the organization operates in. The concept of "social contract" is used to show the expectation of the people regarding the behavior in which the organization should have in performing their activities. As a result, an accountable and transparent local government is already a part of the people's general expectation (Sinaga and Probowo, 2011).

Hypothesis $3 \mathrm{~b}\left(\mathrm{H}_{3 \mathrm{~b}}\right)$ states that audit opinion in the previous year weakens the influence of the region's level of dependence towards the central government on the accountability of the local government financial reporting. The interaction between the regional level of dependency towards the central government and the previous year audit opinion $\left(\mathrm{X}_{2} * \mathrm{X}_{4}\right)$ has a regression coefficient value of $-14,264$ with a sig. value of 0,271 . The sig. value 0,271 is greater than 0,05 , thus hypothesis 3 bis rejected. The research result shows that the previous year audit opinion is not able to weaken the influence of the regional level of dependency towards the central government on the accountability of the local government financial reporting. Even if the previous year audit opinion of the local government was unqualified or adverse, if the local government has a high dependency level, they would tend to have a low financial reporting accountability. If the level of dependency of a region towards the central government is still high, the probability to attain a better opinion would be lower. This could be because the low demand for transparancy and accountability by external parties (Nalurita, 2015).

Hypothesis $4\left(\mathrm{H}_{4}\right)$ states that audit opinion in the previous year can weaken the influence of internal control system weaknesses on the accountability of the local government financial reporting. The interaction between the internal control system weaknesses and the previous year audit opinion $\left(\mathrm{X}_{3} * \mathrm{X}_{4}\right)$ has a regression coefficient value of $-0,496$ with a sig. value of 0,044 . The sig. value 0,044 is smaller than 0,05 , thus hypothesis 4 is accepted.The research result shows that audit opinion in the previous year is able to weaken the influence of internal control system weaknesses on the accountability of local government financial reporting. This means that even if there are internal control system weaknesses found, but the local government has an unqualified audit opinion in the previous year, the accountability of the financial reporting will still be good. If there is a high number of audit findings regarding the internal control system or there is an increase from the previous year, the opinion attained by the city/regency will not necessarily be bad, because this depends on the level of materiality (Alfiani et al., 2017).

\section{CONCLUSION}

Based on the test results and the discussions, it can be concluded that the regional independency level does not influence the accountability of the local government financial reporting; the regional level of dependency towards the central government does not have an influence on the accountability of the local government financial reporting; the internal control system weakness has a negative influence on the accountability of the local government financial reporting; previous year audit opinion is not able to strengthen the influence of regional independence level on the accountability of the local government financial reporting; previous year audit opinion is not able to weaken the influence of the regional level of dependency towards the central government on the accountability of the local government financial reporting; and previous year audit opinion is able to 
weaken the influence of internal control system weaknesses on the accountability of the local government financial reporting.

This research contributes to the development of the agency theory, signaling theory and the theory of bounded rationality. This research is also able to provide additional empirical evidence to the public sector accounting literature, specifically regarding fiscal decentralization, internal control system, and audit opinion in the previous year related to the local government financial reporting. For the local government, this research provides suggestions that can help the government in improving their financial reporting accountability. The test on the influence of the internal control system weakness variable on the accountability of the local government financial reporting attained a significant result. Thus, for the local government to improve their accountability, it is advisable for them to pay heed and optimize the operation of the internal control system of the government. Furthermore, routine evaluations should be conducted on the internal control system. The test on the previous year audit opinion produced empirical evidence that previous year audit opinion is a moderator in the influence of internal control system on the accountability of local government financial reporting, therefore it is advisable for the local government to pay heed to the previous year recommendations.For the people, this research can be used as an information source to expand their knowledge and wisdom related to the accountability of the local government financial reporting.

Based on the research conducted, there are some limitations in this research, one is that this research only use secondary data. Future studies can use additional primary data by utilizing the interview method on related government institutions to enrich the relevant information related to the topic of this research. Furthermore, future research are also advised to expand the scope to other independent variables that can influence the accountability of the local government financial reporting, such as the materiality level variable, corruption level, human resource, or use the fiscal decentralization variable with a different proxy, consider utilizing the Theory of Planned Behavior (TPB) or the Legitimation Theory as the fundamental theory, and expand the research object in order to attain a different research result.

\section{REFERENCE}

Agusti, A. F., Rossieta, H., \& Siswantoro, D. (2014). Faktor Determinan Akuntabilitas dan Transparansi Kementerian/Lembaga. Pasca sarjana Ilmu Akuntansi, Fakultas Ekonomi, Universitas Indonesia, 1-14. Retrieved from http://staff.ui.ac.id/system/files/users/hilda. rosieta/publication/2014-_iv.pdf

Agustina, G. P., \& Riharjo, I. B. (2016). Faktor-Faktor yang Mempengaruhi Kelemahan Pengendalian Intern Pemerintah Daerah. Jurnal Ilmu Dan Riset Akuntansi Sekolah Tinggi Ilmu Ekonomi Indonesia (STIESIA) Surabaya, 5 (4), 1-15.

Ahmad, A. W., \& Septriani, Y. (2008). Konflik Keagenan/ : Tinjauan Teoritis dan Cara Menguranginya. Jurnal Akuntansi and Manajemen, Vol 3, 47-55.

Alfiani, A. N., Rahayu, S., \& Nurbaiti, A. (2017). Jumlah Temuan Audit Atas Sistem Pengendalian Intern dan Jumlah Temuan Audit Atas Kepatuhan Terhadap Opini LKPD Pemerintah Kota/Kabupaten di Jawa Barat. Jurnal Riset Akuntansi Kontemporer (JRAK), 9 (1), 12-19.

Arifianti, H., Payamta, \& Sutaryo. (2013). Pengaruh Pemeriksaan dan Pengawasan Keuangan Daerah Terhadap Kinerja Penyelenggaraan Pemerintahan Daerah (Studi Empiris Pada Pemerintah Kabupaten/Kota di Indonesia). Simposium Nasional Akuntansi (SNA) XVI Manado., (September 2013), 2477-2505.

Atyanta, R. (2010). Analisis Opini BPK atas Laporan Keuangan Pemerintah Daerah (Studi Kasus pada Kabupaten X di Jawa Timur). Jurnal Ilmiah Mahasiswa Fakultas Ekonomi Dan Bisnis Universitas Brawijaya, 1, 1-18. Retrieved from http://jimfeb.ub.ac.id/index.php/ jimfeb/article/view/310

Banimahd, B., Noorifard, Y., \& Davoudabadi, A. (2013). Auditor-Management Alignment and Audit Opinion: Evidence from Iran. Management Science Letters, 3(4), 12171222. https://doi.org/10.5267/j.msl.2013.02.026

Bazerman, M. H. (1994). Judgment in Managerial Decision Making. Singapore: John Wiley and Sons, Inc.

Bennet, R. (2010). Decentralizing Authority After Suharto: Indonesia's "Big Bang," 1998 - 2010, 1-11. Retrieved from http://www.princeton.edu/ successfulsocieties/content/data/policy_note/ PN_id132/Policy_Note_ID132.pdf

BPK Perwakilan Provinsi Bali. (2017). BPK Serahkan LHP Atas LKPD TA 2016 Kabupaten/Kota Se-Provinsi Bali. Retrieved from http://denpasar.bpk.go.id/?p=12229

Darmawati. (2017). Pengaruh Kelemahan Sistem Pengendalian Internal, Ketidakpatuhan Terhadap Perundangundangan, dan Tindak Lanjut Rekomendasi Hasil Pemeriksaan Terhadap Opini BPK RI. Universitas Lampung.

David, R. (2017). Contribution of Records Management to Audit Opinions and Accountability in Government. South African Journal of Information Management, 1-15. 
Deegan, C. (2000). Financial Accounting Theory. Sydney: McGraw Hill Book Company.

Direktorat Jenderal Bina Keuangan Daerah Kementerian Dalam Negeri. (2013). Program Dana Insentif Daerah Mendorong Prestasi Daerah. Retrieved from http://keuda. kemendagri. go.id/artikel/detail/20-program-dana-insentifdaerah-mendorong-prestasi-daerah

Elmaleh, M. S. (2006). The Reliability and Accuracy of Financial Statements. Retrieved from http:// www.understand-accounting.net/TheReliability and Accuracy of financial statements.html.

Erryana, V., \& Setyawan, H. (2016). Determinan Akuntabilitas Pelaporan Keuangan Pemerintah Daerah (Studi Empiris Pada Pemerintah Daerah se- Jawa Tengah). Jurnal Akuntansi Indonesia Universitas Islam Sultan Agung, 5 (1), 1-14.

Fanani, Z., Putra, A. Y., \& Prastiwi, A. (2008). Analisis Pengaruh Volatilitas Arus Kas, Magnitude Accrual, Volatilitas Penjualan, Leverage, dan Siklus Operasi Terhadap Kualitas Laba. The 2nd Accounting Conference, 1st Doctoral Colloquium, and Accounting Workshop Depok, 4-5 November 2008., 4-5.

Fatimah, D., Sari, R. N., \& Rasuli, M. (2014). Pengaruh Sistem Pengendalian Intern, Kepatuhan Terhadap Peraturan PerundangUndangan, Opini Audit Tahun Sebelumnya dan Umur Pemerintah Daerah Terhadap Penerimaan Opini Wajar Tanpa Pengecualian Pada Laporan Keuangan Pemerintah Daerah di Seluruh Indonesia. Jurnal Akuntansi Universitas Riau, 3 (9), 1-15. https://doi.org/10.1017/ CBO9781107415324.004

Fontanella, A., \& Rossieta, H. (2014). Pengaruh Desentralisasi Fiskal dan Kinerja Terhadap Akuntabilitas Pelaporan Keuangan Pemerintah Daerah di Indonesia. Simposium Nasional Akuntansi 17 Mataram, Lombok, 1-24. https:/ /doi.org/10.18196/jai.2016.0053.176-185

Ghozali, I. (2013). Aplikasi Analisis Multivariate Dengan Program SPSS. Semarang: Penerbit Universitas Diponegoro.

Halim, A. (2011). Pengelolaan Keuangan Daerah (Edisi Ketiga). Yogyakarta: UPP AMP YKPN.

Hudaya, M., Smark, C., Watts, T., \& Parulian, S. (2015). The Use of Accountability Reports and the Accountability Forum/ : Evidence from an Indonesian Local Government The Use of Accountability Reports and the Accountability Forum. Australasian Accounting Business and Finance Journal, 9(4), 57-70. https:// doi.org/10.14453/aabfj.v9i4.5

Irmawati, F. D., \& Pratolo, S. (2016). Pengaruh Kinerja Keuangan, Politik Dinasti, dan Kinerja Pemerintah Daerah Terhadap Akuntabilitas
Pelaporan Keuangan Pemerintah Daerah di Indonesia Tahun 2012 - 2013. ACCOUNTING DEPARTEMENT UMY, 1-23. Retrieved from http://repository.umy.ac.id/handle/123456789/ 2756

Jensen, M. C., \& Meckling, W. H. (1976). Theory of the Firm: Managerial Behavior, Agency Costs and Ownership Structure. Journal of Financial Economics, 3(4), 305-360. https://doi.org/http:/ /dx.doi.org/10.1016/0304-405X(76)90026-X

Kawedar, W. (2010). Opini Audit dan Sistem Pengendalian Intern (Studi Kasus di Kabupaten PWJ yang Mengalami Penurunan Opini Audit). Jurnal Akuntansi Dan Auditing Universitas Diponegoro. Retrieved from http://www.ejurnal.com/2016/03/opini-audit-dan-sistempengendalian.html

Kewo, C. L. (2017). The Influence of Internal Control Implementation and Managerial Performance on Financial Accountability Local Government in Indonesia. International Journal of Economics and Financial Issues, 7(1), 293-297. Retrieved from http:\%0Awww. econjournals. com

Malek, M., \& Ahmad, C. A. (2011). The Relationships between Director-Auditor Link and Audit Opinion. Asian Journal of Finance and Accounting, 3(1), 39-55. https://doi.org/ 10.5296/ajfa.v3i1.661

Moisiu, A. (2013). Decentralization and the Increased Autonomy in Local Governments. Procedia Social and Behavioral Sciences, 109, 459463. https://doi.org/10.1016/j.sbspro.2013.12.490

Mudhofar, K., \& Tahar, A. (2016). Pengaruh Desentralisasi Fiskal dan Kinerja Terhadap Akuntabilitas Pelaporan Keuangan Pemerintah Daerah di Indonesia: Efek Moderasi dari Kinerja. Jurnal Akuntansi Dan Investasi, 17(2), 176-185. https://doi.org/10.18196/ jai.2016.0053.176-185

Munawar, Abdullah, S., \& Nadir, N. (2016). Pengaruh Jumlah Temuan Audit Atas SPI dan Jumlah Temuan Audit Atas Kepatuhan terhadap Opini Atas Laporan Keuangan Pemerintah Kabupaten/Kota di Aceh. Jurnal Administrasi Akuntansil : Program Pascasarjana Unsyiah, 5(2). Retrieved from http://www.jurnal. unsyiah.ac.id/JAA/article/view/4516

Nainggolan, A. T., \& Purwanti, D. (2016). Analisis Faktor-Faktor yang Mempengaruhi Transparansi Informasi Keuangan Daerah via Website. SNA XIX Lampung. Retrieved from http:// lib.ibs.ac.id/materi/Prosiding/SNA XIX (19) Lampung 2016/makalah/099.pdf

Nalurita, N. (2015). Pengaruh Sistem Pengendalian Internal, Kepatuhan Terhadap PerundangUndangan, dan Karakteristik Daerah Terhadap Kredibilitas Laporan Keuangan 
Pemerintah di Indonesia. Universitas Sebelas Maret.

Ngoepe, M., \& Ngulube, P. (2013). Contribution of Record-Keeping to Audit Opinions: An Informetrics Analysis of the General Reports on Audit Outcomes of the Auditor-General of South Africa. ESARBICA Journal, 32, 45-54.

Nurdiono, Halim, A., Sugiri, S., \& Gudono. (2015). Pengaruh Proporsi Anggaran dan Faktor Non Keuangan Pada Hasil Audit LKPD di Seluruh Indonesia. Simposium Nasional Akuntansi XVIII Universitas Smatera Utara Medan, 123. Retrieved from http://lib.ibs.ac.id/materi/ Prosiding/SNA XVIII/makalah/113.pdf

Nurhidayati, S. (2017). Pengaruh Desentralisasi Fiskal, Kinerja Penyelenggaraan Pemerintah Daerah dan Tindak Lanjut Rekomendasi Hasil Pemeriksaan BPK Terhadap Opini Laporan Keuangan Pemerintah Daerah di Indonesia. Universitas Lampung.

Rinaldi, T., Purnomo, M., \& Damayanti, D. (2007). Memerangi Korupsi di Indonesia yang Terdesentralisasi, Studi Kasus Penanganan Korupsi Pemerintahan Daerah. World Bank L Justice for the Poor Project. Retrieved from http://siteresources.worldbank.org/ INTINDONESIA/Resources/Publication/ Memerangi_Korupsi_dprd.pdf

Rosadi, S., Siyamto, Y., \& Aisyiah, H. N. (2017). Ketepatan Waktu Penyampaian Laporan Keuangan, Kelemahan Sistem Pengendalian Internal, Kepatuhan Peraturan PerundangUndangan, Status Daerah dan Ukuran Daerah Terhadap Opini Laporan Keuangan Pemerintah Daerah di Pulau Jawa Tahun 2013. Jurnal Ilmiah Ekonomi Islam, 3(2), 99-111.

Safitri, N. L. K. S. A., \& Darsono. (2015). Pengaruh Sistem Pengendalian Internal dan Temuan Kepatuhan Terhadap Opini Audit Pada Pemerintah. Diponegoro Journal of Accounting, 5, 1-12.

Saputra, B. (2012). Dampak Desentralisasi Fiskal Terhadap Korupsi di Indonesia. Jurnal Borneo Administrator, 8 No.3, 293-309. https://doi.org/ $10.1142 / \mathrm{S} 1793993310000160$

Saragih, J. P. (2003). Desentralisasi Fiskal dan Keuangan Daerah dalam Otonomi. Jakarta: Ghalia Indonesia.
Simon, Y., Mahfudnurnajamuddin, Mas'ud, M., \& Su'un, M. (2016). The Role of Apparatus Competence, Internal Control System on Good Governance and the Quality of Financial Statement Information. ResearchersWorld Journal of Arts, Science and Commerce, VII(4), 123-133. https://doi.org/10.18843/rwjasc/ v7i4/14

Sinaga, Y. F., \& Probowo, T. J. W. (2011). Analisis Faktor-Faktor yang Mempengaruhi Pelaporan Keuangan di Internet Secara Sukarela oleh Pemerintah Daerah. Universitas Diponegoro, 1-33. Retrieved from http://eprints.undip.ac.id/ 28576/1/JURNAL_YURISCA_C2C007142.pdf

Suryanto. (2017). Akuntabilitas Pelaporan Keuangan Pemerintah Daerah di Indonesia. Jurnal Agregasi, 5(1), 72-91.

Syahruddin, H., P. (2006). Desentralisasi Fiskal/ : Perlu Penyempurnaan Kebijakan dan Implementasi yang Konsisten. Retrieved from http://repository.unand.ac.id/23271/1/fiskal.pdf

Wasistiono, S. (2002). Kapita Selekta Penyelenggaraan Pemerintahan Daerah (Edisi Kedua). Bandung: Fokusmedia.

Winarko, B., \& Mahadewi, L. (2013). Tinjauan Beberapa Model Teori Dasar Adopsi Teknologi Baru. Media Bisnis, 5(1), 24-34.

Yudani, N. N. (2008). Desentralisasi Fiskal Dalam Hubungannya dengan Pendapatan Asli Daerah (PAD) dan Belanja Pembangunan di Lingkup Provinsi Bali. Universitas Gajah Mada. Retrieved from http://etd.repository. ugm.ac.id/index.php? mod=penelitian detailandsub $=$ PenelitianDetailandact $=$ viewandtyp=htmlandbuku_id=39704

Yuliati, R., Raharjo, S. S., \& Siswantoro, D. (2017). Accountability and Incumbent Re-election in Indonesian Local Government. International Research Journal of Business Studies, 9(3), 157-168.

Yuswanto. (2007). Kedudukan Dana Alokasi Umum (DAU) dalam Hubungan Antara Pusat dan Daerah Berdasarkan Asas Otonomi. Fiat Justisia Jurnal Ilmu Hukum Universitas Lampung, 1, 1(Januari-April), 73-85. 